\title{
Russian-Kazakh Cooperation as a Factor in the Implementation of the Eurasian Idea
}

\author{
Albert V. Beloglazov ${ }^{1} \&$ Ildar G. Akhmetzyanov ${ }^{1}$ \\ ${ }^{1}$ Kazan (Volga Region) Federal University, Kazan, Russia \\ Correspondence: Albert V. Beloglazov, Kazan (Volga Region) Federal University, 420008, Kazan, Kremlyovskaya \\ Street 18, Russia. E-mail: Albert.Beloglazov@kpfu.ru
}

Received: June 2, 2015 Accepted: June 15, 2015 Online Published: June 29, 2015

doi:10.5539/jsd.v8n5p176

URL: http://dx.doi.org/10.5539/jsd.v8n5p176

\begin{abstract}
Conducted research is relevant due to the rapid development of integration processes at the post-Soviet space at the beginning of XXI century. The aim of the article is to analyze Russian and Kazakh collaboration as the driving force of Eurasian integration processes. The main method of the research of this issue is Eurasianism, through the prism of which Russian and Kazakh collaboration is under consideration. The results of the research prove the fact that Russia and Kazakhstan have lots of similar features and converging factors of geographic, historical, ethnic and confessional nature. The economics of the countries are inter-supplementary; their political approaches to the most global and regional issues are alike. In general Russia and Kazakhstan have not only good neighbourly and collaborating, but also inter-allied bilateral relations. This marks joint and active advance of Eurasian integration processes and the development of Eurasian idea in general. The materials of the article may be useful in conducting scientific research on the issues of external policies of Russia and Kazakhstan, providing lectures and seminars in training and planning specific measures on further advance of integration processes at the post-Soviet space.
\end{abstract}

Keywords: Eurasian idea, Russian Federation, Republic of Kazakhstan, integration processes, Collective Security Treaty Organization, Eurasian Economic Community, Customs Union, Common Economic Space, Eurasian Union

\section{Introduction}

$21^{\text {st }}$ century has brought new threats and challenges, as well as very high rates of political, economic and social processes. Now, under the conditions of the aggravation of economic competition and political pressure, only integration into larger international organizations allows individual states to improve their competitiveness and preserve the sovereignty, as well as to influence the decisions of the international community. For the countries of the Commonwealth of Independent States (CIS), the integration with the neighboring states of the former Soviet Union is the most natural. The matter of such integration is not only about historical, economic, political, cultural and humanitarian background. CIS countries share common territory - Eurasia - in the terms expressed in the Eurasian idea.

Globally speaking, Eurasia is a huge continent, comprising about three-quarters of all human resources demographic, energy, mineral, biological. At large, there are dozens of states and hundreds of peoples and cultures. However, from the perspective of Eurasian idea, Eurasia is approached as a part of the continent called the Heartland or Geographical Pivot of History by geopolitics, classical authors and scholars, starting with Halford Mackinder (Mackinder, 1996). In general, it coincides with the territory of the Russian Empire in the early $20^{\text {th }}$ century.

Ii is interesting that the Eurasian idea is more popular among all the post-Soviet states, especially in Russia and Kazakhstan, which drive the development of Eurasian integration. Why is this happening?

Number of western researchers, mainly Americans, explains Kazakhstan's commitment to the idea of Eurasianism as a least-evil solution aimed at securing themselves from Russia. For instance, John Lepingwell explained one of the reasons of the Eurasian Union idea turned up in the administration of President N.A.Nazarbayev with the presence of Russian speaking majority in Kazakhstan and its geographic proximity to Russia. According to him, these factors left Kazakhstan president in a very difficult situation, forcing him on the 
one hand to seek closer ties with the northern neighbour and offer Eurasian Union, and on the other hand made him in every way avoid the issues of dual citizenship not to have his power eroded in the republic (Lepingwell, 1994).

Frederic Starr also concluded that Kazakhstan is burdened with ethnic and territorial issues with Russia (Starr, 1996). Zbignev Brzezinski clarified: "due to the fact that in the north-western and north-eastern regions of Kazakhstan Russian colonists dominates significantly, Kazakhstan could face the threat of territorial division if the relations between Kazakhstan and Russia worsened" (Brzezinski, 1997).

The attempts to focus attention at the "issues" of relations between Kazakhstan and Russia are caused by understanding that the two Eurasian countries might become the basis for the future strong union which is accepted by the US as a new version of USSR. Hillary Clinton was the person who made a very explicit statement about it. Commenting on the Russian offer about the creation of Eurasian Union together with the republics of post-Soviet space, she named this plan "new attempt of sovietization of the region" and announced that the United States try to work out effective measures to slow down or prevent this process (Gvosdev, 2012).

We would try to determine the objective reasons of Kazakhstan's and Russia's commitment to Eurasian idea.

\section{Methodological Framework}

In order to understand why Russia and Kazakhstan are the champions of the Eurasian idea, initiating the Eurasian integration, as well as to determine the results of their overall partnership, in our opinion, it is necessary to identify the strategic factors of the Eurasian ideas in the first place, as well as its developmental milestones.

After that it will be possible through the prism of the Eurasian ideas consider geographic, ethno-confessional and historical background of Russian-Kazakh cooperation, explore the relationship between Russia and Kazakhstan in the political and economic spheres, as well as to determine the role of both countries and their cooperation in the promotion of Eurasian integration.

Eurasian idea was most clearly represented in the works of the movement of the Eurasians emerged in the 1920s. The division of the map of Eurasia not into two traditional but three parts - Europe, Asia and Russia-Eurasia became a starting point and laid the corner stone.

First Eurasians were Russian scientists Nikolai Sergeevich Troubetzkoy, Georgi Vladimirovich Vernadsky, Pyotr Petrovich Suvchinsky, Georgi Vasilievich Florovsky, especially Pyotr Nikolaevich Savitsky, who asserted that the Ural Mountains are only a formal delimiter of the continents. To the west and east of them climate, landscape, flora, fauna, types of economy and culture are almost identical. At the same time, areas, located both to the west and to the south of Russia, have striking differences in natural factors and types of civilizations.

Thus, in his project article "Eurasianism", referring to the Eurasians, P.N. Savitsky emphasized: "The fact is that most of the array of lands of the Old World, where the former geographers distinguished two continents "Europe" and "Asia", they began to distinguish the third, middle mainland - "Eurasia", and the latter got its name." (Savitsky, 2003). In his other famous work "The geographic and geopolitical foundations of Eurasianism" P.N. Savitsky stated that "the nature of Eurasia leads people to the need of political, cultural and economic integration much more than we have seen in Europe and Asia." (Savitsky, 2002).

Thus, the Eurasians take up position that the integration processes in the Eurasian continent, as the median continent, are much more natural than in other parts of the continent. These processes affect the mentality and national character of the peoples living in this territory. However, no nation can be considered uncultured or underdeveloped, as traditionally believed by Eurocentrists. The leader of the first wave of Eurasians N.S. Troubetzkoy dedicated his article "Europe and Mankind" to the justification of this important idea (Troubetzkoy, 2003).

Eurasians did a lot especially to prove the equivalence of the steppe cultures of nomadic peoples and sedentary population. Their relationship is largely determined by complementarity. Complementarity of peoples led to cooperation and even to friendship. According to P.N. Savitsky, "No wonder that there is the spirit of "brotherhood of peoples" over Eurasia, which has its roots in centuries-old cultural contacts and mergers of peoples of different races." (Savitsky, 2002).

After the Second World War, the Eurasian idea continued to evolve, and could be particularly noticed in the works of L.N. Gumilev. He stated that the Slavic and Turkic elements, culture of farmers and pastoralists, forest and steppe were equal elements in the creation of a great state, and its super ethnos building it up. According to him, the general methodological principle of Eurasianism is Eurasian cultural polycentrism. (Gumilev, 2008). Contribution of L.N. Gumilev into Eurasian idea was particularly appreciated by the Turkic peoples of Eurasia, 
especially by Russia and Kazakhstan. No wonder that one of the largest universities in Kazakhstan - Eurasian National University in Astana - is named after L.N. Gumilev. In Kazan, the capital of the Republic of Tatarstan, a portrait sculpture of L.N. Gumilev is installed in the central square of the city.

After the collapse of the Soviet Union, the Eurasian idea acquired a new and very special importance. Divided republics of the Soviet Union, which became independent states, shared common economic and cultural space, predetermined by nature and history. It is not surprising that integration trends began to emerge in many of them. However, the Commonwealth of Independent States could not become a tool of full integration. It was more of a framework union, within the boundaries of which a variety of integration processes could be developed, since the CIS Charter did not prohibit internal association of its members.

Leaders of the country-members of the Commonwealth began to look for alternative integration options. Thus, the first attempts to implement the integration trends in the internal structures of the CIS - Collective Security Treaty of 1992 and the Customs Union in 1995 - were only declarative forums, rather than full-fledged organizations.

During this period, the President of the Republic of Kazakhstan N.A. Nazarbayev was among the first leaders of the former Soviet republics who appealed to the Eurasian idea and proposed the idea of a fundamentally new Eurasian integration. Back in March 1994, during the official visit to Russia, at the meeting in M.V. Lomonosov Moscow State University with the students and professors of the university and Russian politicians, he first suggested the idea of establishing the Eurasian Union.

A little later, June 3, 1994, there was published a draft document "On the formation of the Eurasian Union." The document consisted of two parts. The first stated that "at the present time, all the CIS countries continue to experience a crisis in all spheres of public life - economy, politics, ideology, international relations, economic and social tension grows" (Nazarbayev, 2004). To overcome the negative trends N.A. Nazarbayev suggested "a project to create a new integrative association called "Eurasian Union" (EAU)." (Nazarbayev, 2004). The second part reflected the principles of association, as well as areas in which it was necessary to initiate the integration process. Among them were the economy, defense, environment, science, culture and education. It is interesting that, according to N.A. Nazarbayev "capital of the EAU could be one of the cities at the crossroads of Europe and Asia, for example, Kazan" (Nazarbayev, 2004).

However, in the 1990s the idea of EAU failed to appeal to both the Russian leadership and the political elites of post-Soviet states. Only at the turn of the $20^{\text {th }}-21^{\text {st }}$ centuries, the situation began to change. Eurasian idea was once again in demand after the election of the President of the Russian Federation V.V. Putin.

\section{Results}

\subsection{Geographic, Ethno-Confessional and Historical Factors of Russian-Kazakh Partnership}

A number of factors unite and bring together the Russian Federation and the Republic of Kazakhstan. Judging by their geographical position only they can be called fully Eurasian, in both senses, for they alone of all the states of the CIS, are both in Europe and in Asia. Kazakhstan is the largest of the former Soviet republics after Russia. In the world, it is the ninth largest in terms of total area (Gumppenberg \& Steinbach, 2004). In addition, the length of their common border by land is more than 7.500 square kilometers, which is the longest land border in the world. In addition, Russia and Kazakhstan are united by sharing the Caspian Sea. There is no conflict, though some Western scholars argued that Kazakhstan burdened territorial issues with Russia (Starr, 1996). Kazakhstan is the largest country in the world, which has no gate to the world ocean, so Russian communication lines are extremely important. For Russia, the Kazakh communication lines are of great importance as they link it with the other Central Asian states.

In terms of ethno-confessional relations Russia and Kazakhstan are also similar. Basic ethnic groups of their populations are represented by the Slavs and Turkoman in terms of ethno-linguistic origin, and considering their religions, they are Orthodox Christians and Sunni Muslims. By the end of the $20^{\text {th }}$ century, even after the mass migration of Russians from Kazakhstan to Russia, 4.48 million people stayed there, comprising $30 \%$ of the Kazakhstan population of 14.95 million people before it. Now, according to the latest census of 2009 , Russian population in Kazakhstan is about 3.8 million people, representing almost a quarter of 16 million people of the Republic (Census of the Republic of Kazakhstan, 2010). Even the first Eurasians expressed the idea that the Slavs and Turkoman peoples are equal builders of common integrated space of Eurasia. The ethnic composition of our countries also determines active development of the Eurasian idea here.

Historically, Kazakhstan and Russia are united by the period of co-existence being part of one state for longer time than other Central Asian republics. 260 years passed from the moment when the Kazakhs of the Little 
Horde got under the protectorate of the Russian Empire to the collapse of the Union of Soviet Socialist Republics (USSR) In addition, the Kazakhs comparing to the other nations in the region have no reason for historical grievances. Their joining Russia was voluntary and guaranteed protection from Kokand and Khiva khanates as well as from Jungars. Over the years the Kazakhs lived in the Russian Empire and the Soviet Union cities were built, industry grew, the Kazakh land was actively cultivated and developed. It stands to reason that the vast majority of the Kazakhstan people - 94.1\%, were in favor of preserving the Soviet Union during the referendum held in March 199. They supported the idea of coexistence with Russia choosing to share one common state (Landau \& Kellner-Heinkele, 2001). And most importantly, over the years there was a feeling of the historical affinity among the nations, which did not disappear even after the collapse of the USSR. According to Martha Olcott, "many Russians - and even Kazakhs - still hope that one day the two countries and two peoples will officially unite" (Olcott, 2002).

\subsection{Political Cooperation}

Politically, Russia and Kazakhstan hold similar positions concerning many major issues of our time. They stand for multipolar world, for refusing from violence methods to resolve international conflicts. The "Declaration between the Russian Federation and the Republic of Kazakhstan on eternal friendship and alliance in the $21^{\text {st }}$ century", Kazakhstan and Russia have pledged to cooperate closely in the field of foreign policy, together seeking for ways to improve the situation and to ensure peace and security in the Eurasian region and all over the world. In addition, they agreed to work together and take all possible measures to eliminate the threat or counter acts of aggression against them by any state or group of states, and, if necessary, render appropriate assistance to each other, including military one (Declaration between the Russian Federation and the Republic of Kazakhstan, 1998).

Kazakhstan, following the lead of Russia, was the first country in the world to voluntarily renounce nuclear weapons. This, according to N.A. Nazarbayev, "is unprecedented contribution to shaping the global security system, to creating peace in the world" (Nazarbayev, 2001). After this initiative, the military-political cooperation, especially in the field of security, has always strengthened. So, a number of Russian military facilities is located on the territory of Kazakhstan: Baikonur Cosmodrome, transport aviation regiment in Kustanai, Radio Radar Center in Priozersk, strategic Protection Against Aircraft testing ground in Sary-Shagan.

Russia actively supported Kazakhstan in the nomination process for its chairmanship in the Organization for Security and Cooperation in Europe in 2010. Both Kazakhstan and Russia are key players in the military-political integration organizations that provide regional security in Central Asia: the Collective Security Treaty Organization (CSTO) and the Shanghai Cooperation Organization (SCO). Moreover, these organizations, especially the CSTO can be considered as a real manifestation of the Eurasian idea.

Every year, the heads of states hold more than ten summits, both bilateral and using summits' platforms. During one of these meetings in 2013 the Russian-Kazakh agreement on good-neighborliness and alliance in the $21^{\text {st }}$ century was signed, which serves as guidelines for the parties in the political relations at present. (Russian-Kazakh agreement, 2013). The choice of words of its title emphasizes the unprecedented high level of political relations.

\subsection{Economic Partnership}

Despite the success in political cooperation, factors most notably affecting the bilateral relations are economic factors. Economy of Russia and Kazakhstan are very similar, both are driven by raw materials industry and are mainly based on the production and export of hydrocarbons, as well as metallurgy. In addition, both Russia and Kazakhstan are among the largest producers of grain. Furthermore, both countries are focused on innovative development.

Bilateral economic cooperation between Russia and Kazakhstan began immediately after the collapse of the Soviet Union, even before the formal establishment of diplomatic relations on October 22, 1992. In 1990s, despite the fact that Russia was mainly focused on the countries of the West, its economic cooperation with Kazakhstan developed but rather slowly. Its main and essential factors were the interdependence and complementarity of national economies. At that time, the only active routes for transporting Kazakh oil to the world market were the oil pipelines running through Russia. In its turn, connections between Russia and other Central Asian states were carried out through the territory of Kazakhstan. There were no alternatives for Space center for launching civilian satellites and spaceships of Russia located in Kazakhstan Baikonur, which was leased in 1994. Yet, in the first half of the 1990s, many important agreements looked good only on paper. 
In the second half of the 1990s, after the change of leadership in the Ministry of Foreign Affairs, plans and projects started to be carried out, finally, the parties began to move on to the real economic steps. This was particularly noticeable in the energy sector, where Russian companies entered economic interest groups and consortiums for the development of the largest raw hydrocarbon deposits in Kazakhstan, including the Tengiz and Karachaganak. The Russian company Lukoil played the most prominent role. In addition, during this period Russia actively promoted and implemented projects for the transportation consortium (CPC) with the route of Tengiz-Novorossiysk-Astrakhan. Transit quota of Kazakh oil through other Russian oil pipelines was also increased. In addition, the results of this period, as may be noted, are recovery and initiation of the parallel operation of power systems of the two countries, as well as agreement on the mutual supply of natural gas.

Cooperation in the sphere of foreign trade rapidly developed. In the 1990s Russia was the main foreign trade partner of Kazakhstan: it accounted for 20\% of Kazakhstan's exports and 50\% of imports. Foreign trade turnover between Russia and Kazakhstan by 2000 reached $\$ 4.3$ billion. However, serious problems in the economic cooperation in this period were different degree of economy centralization and the financial crisis of 1998 (Beloglazov, 2011).

Starting with 2000, after the Russian president V.V. Putin elections, Russia's attitude to Kazakhstan changed. There emerged the idea of unique geopolitical alliance between the two countries, which was especially beneficial for the economic cooperation. Partnership between Russia and Kazakhstan in the energy industries took a more active and far-reaching step. Despite the emergence of the pipeline to China Atasu-Alashankou in 2005, the bulk of the transit of Kazakh oil to foreign markets was and is still implemented through the territory of Russia (Westphal, 2007).

In 2002, there was signed intergovernmental agreement according to which Atyrau-Samara pipeline transit produced no less than 15.5 million tons of oil annually and Makhachkala-Novorossiysk-Tikhoretsk - additional 5.5 million tons. Besides, in 2001 CPC pipeline began transporting more than 25 million tons of Kazakh oil annually. Cooperation between two countries had been considerably promoted after the visit of President Vladimir Putin to Kazakhstan in January 2004 and signing a number of long-term contracts in the oil sector. Also during the visit of N.A. Nazarbayev to Moscow in April 2006, an agreement was reached to expand the capacity of the CPC to 67 million tons (Lousianin, 2007).

Almost the same high rate of development can be seen in the Russian-Kazakh cooperation in the gas sector. In May 2002 a joint venture "KazRosGas", founded by the Russian "Gazprom" and Kazakhstan "KazMunaiGas", was specially established for this purpose. This joint venture transports gas through the Russian territory from Kazakhstan to the other CIS countries.

Forum held in Uralsk in October 2006 with the participation of Russia and Kazakhstan presidents and other border regions' authorities had a great impact on the development of gas cooperation. There was signed intergovernmental agreement on the establishment of a joint venture on the premises of the Orenburg gas processing plant. It was assumed to finance the reconstruction of the plant on a parity basis and to jointly operate it and co-operate in the future. It was also decided to process gas condensate transported by pipeline "Aksai Orenburg" from Karachaganak field in the plant, and also to share the products on principles of parity.

It should be noted that the Karachaganak is one of the largest gas condensate fields in the world. Its development is carried out by four partners of the international consortium: BG Group (UK), ENI (Italy), Chevron (USA) and Lukoil (Russia) (Karachaganak project, 2005). Thanks to personal interviews with staff members when visiting the field, the author came to conclusion that the jobs in the Russian sector of gas production were most popular among the local population. At the same time it showed higher wages and more humane attitude to employees as compared to western sectors.

In addition, the energy system of Russia and Kazakhstan in 2000 started to fully operate in parallel mode in which mutual deliveries of electricity and coal were carried out. In 2005, it was agreed to establish a joint Russian-Kazakh venture on the premises in the public company "Ekibastuz regional power station-2". In addition, the program developed to create a common electricity market of Russia and Kazakhstan began. Cooperation in the nuclear power industry developed. Thus, in 2002, joint uranium mining began in the Kazakh oil fields. The joint venture of Russia, Kazakhstan and Kyrgyzstan "Zarechnoe" works in this area.

During 14 years of the new century, Kazakhstan remained among the main trade partners of Russia. The maximum amount of the pre-crisis trade turnover in 2007 amounted to more than 16.5 billion dollars. In 2008-2009, due to the global financial crisis, trade decreased. However, in 2010 the trade turnover between Russia and Kazakhstan began to grow, and in 2013 amounted to 26.5 billion dollars (XI Russia-Kazakhstan Interregional Cooperation Forum, 2014). 
Interregional collaboration is actively developed between two states. 76 Russian entities established economic and trade cooperation with Kazakh partners. Direct cross-border contacts of Russian and Kazakh regions account for more than half of the turnover (Academic Educational Forum on international Relations, 2011). Interregional cooperation forums are regularly held. It was XI Forum on 'Innovations in the Hydrocarbon Sector' held on $30^{\text {th }}$ September, 2014, in Kazakhstan Atyrau with the participation of the presidents V.V. Putin and N.A. Nazarbayev (XI Russia-Kazakhstan Interregional Cooperation Forum, 2014).

\section{Discussion}

In our opinion, the whole complex of geographical, historical, ethnic and religious, political and especially economic factors, in the Russian-Kazakh cooperation led to the fact that both countries are not only partners and allies, but also began to promote co-integration projects. As evidence, we consider the role of both countries in the Eurasian economic integration projects.

In May 2000, V.V. Putin launched an initiative to transform the Customs Union of the 1990s to a full-fledged international economic organization. It seems very essential that the Treaty on the establishment of the Eurasian Economic Community (EAEC) was signed in Astana on October 10, 2000. The presidents of Belarus, Kazakhstan, Kyrgyzstan, Russia and Tajikistan signed it. Therefore, there was the first multilateral organization with the international status, vested with broad powers in matters of economic integration and interaction. Even its very name emphasizes that the Eurasian idea got a new start. In 2006, Uzbekistan joined the organization, but suspended its membership in 2008.

The treaty was based on the concept of close trade and economic cooperation for "effective promotion of the formation of ... Customs Union and Common Economic Space" (Treaty on the establishment of the Eurasian Economic Community, 2003). The chief administrative officer of the Community, pursuant to the Treaty, is Secretary-General of the Eurasian Economic Community. In the entire history of the organization, there were two Secretaries-General - Russian Grigory Rapota and Kazakhstani Tair Mansurov. This clearly shows that Russia and Kazakhstan are the main driving forces of the economic integration in the post-Soviet space.

In 2006, Russia and Kazakhstan established the Eurasian Development Bank (EADB), which was to encourage investment in trade and foster economic ties between its members. Soon, Armenia, Belarus and Tajikistan joined the bank. However, Russia and Kazakhstan are still the backbone of the project. Thus, Russia invested 2/3 of its share capital, and the headquarters of the bank is located in Kazakhstan. The Bank became a major catalyst not only for economic, but also for the whole integration processes in the CIS.

In October 6, 2007, an agreement between Belarus, Kazakhstan and Russia on the establishment of a single customs territory and the formation of the new Customs Union was concluded. On November 28, 2009 forty international treaties, which formed the basis of the Customs Union, were signed in Minsk, and in July 2010, it came into effect. There was canceled transport control on the Russian-Belarusian border starting from April 1, 2011, and on the border between Russia and Kazakhstan - from July 1, 2011. It was moved to the external borders of the Customs Union (Mescheryakov, 2012). The move marked a deepening of economic integration between the three members of the CIS, and the next stage of the development and implementation of the Eurasian idea. There is no doubt that over time, the Customs Union will grow larger. Currently Kyrgyzstan and Armenia are in the process of joining the CU. From the $1^{\text {st }}$ of January 2012, the countries of the Customs Union declared the Common Economic Space, though all its integration agreements came into effect in July 2012.

Finally, the contract on the establishment of the Eurasian Economic Union can be singled out as an important up to date achievement. Agreement on its establishment was achieved in December 2010, at the summit of the Eurasian Economic Community. A year later, in November 2011, there was signed a declaration on Eurasian economic integration in Moscow. Overall, on May 29, 2014, again in the Kazakh capital Astana V.V. Putin, N.A. Nazarbayev and A.G. Lukashenko signed an agreement on the establishment of the Eurasian Economic Union, which will come into force on the $1^{\text {st }}$ of January 2015.

\section{Conclusion}

Summarizing, we can draw the following conclusions. Eurasian idea, which originated in the 1920s, proclaimed the desire for integration and cultural polycentricism on the continent of "Russia-Eurasia" different both from Europe and from Asia. Having passed several stages of the development and transformation, the Eurasian idea proved popular at the beginning of the $21^{\text {st }}$ century. Based on its new understanding there were launched Eurasian integration processes. At the same time, it has been most popular in Russia and Kazakhstan.

Russia and Kazakhstan have many similarities and factors that bring them together. Geographically, these are Eurasian territory, huge area, the length of the total land border, unstrained joint possession of the Caspian Sea. 
In the ethno-religious terms, it is support for the two ethnic groups - Slavic and Turkic, and two confessions Orthodox Christianity and Sunni Islam. In historical terms, it is voluntary membership of Kazakhs in Russia, more than two and a half centuries of co-existence in the same state, the construction of cities, infrastructural and industrial development of virgin lands.

All these similarities imply active political cooperation. It involves regular meetings at the highest level, the similarity of the main positions on the key issues of the present day, military-technical cooperation, security cooperation and the active promotion of the military-political Eurasian integration projects - the SCO and the CSTO.

The most visible and effective is the economic partnership. It is based on the similarities and complementarity between national economies. The most successful is the cooperation in the energy sector - production, transportation and processing of oil, gas, coal and uranium, as well as the establishment of a common energy system. Trade turnover and cross-border inter-regional cooperation is steadily growing.

All these factors allowed the Russian-Kazakh relations to move to a full-fledged alliance level, which was strategic framework of the Eurasian economic integration. Its first step was the establishment of the Eurasian Economic Community, the second was the foundation of the Customs Union of Russia, Kazakhstan and Belarus, the third one implied setting up the Common Economic Space, and the fourth - the Eurasian Economic Union. This union must be the subject of a special scientific research after it becomes operational in 2015 .

Following the deepening of economic integration there automatically increases the degree of political trust and unity in the vision of the key strategic issues. Therefore, the author predicts, after several years of implementation of the fourth stage, the fifth one - the establishment of the Eurasian Union with strong political, cultural and humanitarian component, effective supranational bodies, common currency.

Thus, we see that the partnership and alliance between Russia and Kazakhstan fosters the development of integration processes within the CIS, serve as a powerful catalyst for the formation of one Eurasian economic, political and humanitarian space. Thus, the Eurasian idea moves to a new level of implementation.

\section{Recommendations}

Materials of the article might interest scientists, specialising in the sphere of International Relations and Regional Studies, who conduct researches into modern external policy of Russian Federation and Kazakhstan Republic, as well as integration processes at the post-Soviet space. Also the materials might be useful for students and postgraduates training in the corresponding speciality.

\section{Acknowledgments}

The work is performed according to the Russian Government Program of Competitive Growth of Kazan Federal University

\section{References}

Academic Educational Forum on international Relations. (2011). International relations in Central Asia. Moscow: Aspect Press.

Beloglazov, A. V. (2011). Formation of Russia's policy in Central Asia. Kazan: Kazan University.

Brzezinski, Z. K. (1997). The grand chessboard: American primacy and its geostrategic imperatives. New York: Basic books.

Census of Population of the Republic of Kazakhstan - 2009. Brief results. Statistical collection. (2010). Astana: Agency of the Republic of Kazakhstan on Statistics.

Declaration between the Russian Federation and the Republic of Kazakhstan on eternal friendship and alliance for in the XXI century. (1998). Diplomatic Bulletin, 8, 32-34.

Gumilev, L. N. (2008). Rhythms of Eurasia. Moscow: AST.

Gumppenberg, M. C., \& Steinbach, U. (2004). Zentralasien. Geschichte. Politik. Wirtshaft. Ein Lexikon. München: Druckerei C.H. Beck.

Gvosdev, N. (2012). The Realist Prism: U.S. Stance on Eurasian Union Threatens Russia Reset. In World Politics Review. December, 14. Retrieved May 3, 2015, from http://www.worldpoliticsreview.com/articles/12569/the-realist-prism-u-s-stance-on-eurasian-union-threaten s-russia-reset\#

Karachaganak project. (2005). Publishing House of Partners in the Karachaganak venture. 
Landau, J. M., \& Kellner-Heinkele, B. (2001). Politics of Language in the ex-Soviet Muslim States. Azerbaijan, Uzbekistan, Kazakhstan, Kyrgyzstan, Turkmenistan and Tajikistan. London: Horst and Company.

Lepingwell, J. R. (1994). The Russian Military and Security Policy in the "Near Abroad". Survival, 36(3), 70-92. http://dx.doi.org/10.1080/00396339408442751

Lousianin, S. G. (2007). Eastern policy of Vladimir Putin. Russia's return to the "Big East." 2004-2008. Moscow: AST - North - West.

Mackinder, H. J. (1996). The Geographical Pivot of History. In Democratic Ideals and Reality (pp. 175-193), Washington, DC: National Defense University Press.

Mescheryakov, K. E. (2012). Russia's foreign policy in Central Asia: problems and trends, the path of modernization in order to increase efficiency. St. Petersburg: Scythia-print.

Nazarbayev, N. A. (2001). Ten years, equal to a century. Speech by Nursultan Nazarbayev at the ceremonial meeting dedicated to the 10th anniversary of independence of Kazakhstan. Almaty: Atamura.

Nazarbayev, N. A. (2004). On the formation of the Eurasian Union. Strategy independence. Almaty: Atamura.

Olcott, M. B. (2002). Kazakhstan: Unfulfilled Promise. Washington, D.C.: Carnegie Endowment for International Peace.

Russian-Kazakh agreement on good-neighborliness and alliance in the XXI century. (2013). In site REGNUM. Retrieved May 3, 2015, from http://regnum.ru/news/polit/1730836.html\#ixzz3EhEZssUr

Savitsky, P. N. (2002). Geographical and geopolitical foundations of Eurasianism. In Fundamentals of Eurasianism (pp. 297-304). Moscow: Arctogaia center.

Savitsky, P. N. (2003). Eurasianism. In Classical geopolitics XX Century (pp. 653-676). Moscow: AST.

Starr, F. S. (1996). Making Eurasia Stable. Foreign Affairs, 1, 80-92. http://dx.doi.org/10.2307/20047469

Treaty on the establishment of the Eurasian Economic Community. (2004). In System history of international relations in four volumes. 1918-2003. Ed. A.D. Bogaturov. Vol. four. Documents. 1945-2003 (pp. 550-554). Moscow: Academic Educational Forum on International Relations.

Troubetzkoy, N. S. (2003). Europe and mankind. In Classical geopolitics XX Century (pp. 31-105). Moscow: AST.

Westphal, K. (2007). Wettlauf um Energieressourcen. In Mactmosaik Zentralasien. Traditionen, Restriktionen, Aspirationen (pp. 463-478). Bonn: Lizenzaufgabe für politische Bildung.

XI Forum of Interregional Cooperation of Russia and Kazakhstan. (2014, September 30). In Official site of the President of the Russian Federation. Retrieved May 3, 2015, from http://kremlin.ru/news/46700

\section{Copyrights}

Copyright for this article is retained by the author(s), with first publication rights granted to the journal.

This is an open-access article distributed under the terms and conditions of the Creative Commons Attribution license (http://creativecommons.org/licenses/by/3.0/). 